\title{
How to Rewrite the History of Historiography? Prolegomena for a History of the Truth in History
}

\section{Guillermo Zermeño Padilla}

\author{
gmoz@colmex.mx \\ Professor/Researcher \\ El Colegio de México, A. C., Centro de Estudios Históricos \\ Camino al Ajusco No. 20, Col. Pedregal de Sta. Teresa \\ 10740 - México - DF \\ Mexico
}

\begin{abstract}
How to rewrite the history of historiography at the beginning of this century? This paper tries to answer this question using just four words: history, science, truth and credibility. The revision and transformation that has been done over the categories, concepts or ways of representing history, created during the nationalist modernity, leads us to question how is it possible to write history nowadays, since when those old contents and forms that settled historiographical commonplaces produced in the $19^{\text {th }}$ and $20^{\text {th }}$ centuries seem to have become exhausted. Therefore, we try to show how the crisis of a historical epistemology of "naturalistic" character gave rise to the possibility of considering historical discipline as part of a larger phenomenon: that of culture and its relationship to how societies remember or forget. At the same time, this displacement has also implied the construction of another class of social memory: the opening to the understanding of history as a kind of cultural memory.
\end{abstract}

362 Keywords

History; Truth; Discourse.

Received in: 12/6/2013

Approved in 7/18/2014 
When approaching some recent historical works, we have the impression that contemporary historiography has become an enormous trunk of curiosities; of stories and research dedicated to amaze and astonish us with all those things that we ignore about the past or simply not even imagine that they could have happened, many of them undoubtedly, of great interest. However, we might wonder about the limits of this proliferation of stories that come to us every day and keep coming across through different ways and communicative support. An accumulation of historical stories, that might remind us of that fascination, emerged in the pre-modern period of antiquarian history: the taste for collecting objects and materials, eccentric and exotic. ${ }^{1}$ This happens, of course, not only in our tongues. Text books and tales, no doubt fascinating for their novelty and their critical approach that, in many cases, oblige us to modify and revise our concepts of the past or forms on how a period or a specific phenomena have been wanted to be understood, that no doubt respond to the new sensibilities and cultural atmospheres of our presents.

At the same time, it can be seen that many of these "new" histories, above all those dedicated to the pre-modern period, coincide in their criticism to many of the historical discourses emerged and manufactured during the period of nationalist modernities. ${ }^{2}$ In that sense, analogous to the critical diagnosis of the "philosophical discourse of modernity" of the German sociologist Jurgen Habermas (1989), a significant gallery of historians, might be glimpsed, who have taken on the task of reviewing and questioning, through rigorous analysis, many of the historiographical commonplaces settled during the period between the $19^{\text {th }}$ and $20^{\text {th }}$ centuries. Discourses and stories, which are offered as the utter truth of the past, at the same time they conceal, above all, the way how these "truths" were produced. And great part of their strength and validity are found in the artifice of showing and hiding, at the same time, a part of the truth on which the assertions and representations of the past are sustained. For example, a recent investigation about the history of the concept of Archive has been found in some treatises of the $18^{\text {th }}$ century, about how the erudite antiquarian was advised to keep to himself a part of the secret, not to fully show the "truth" and, in this way, maintain the elements of surprise, suspense and attraction in his readers and consumers of such stories (ZERMEÑO PADILLA 2012, p. 13-57).

It would be about stories of ancient things, critical of the historical discourse elaborated by modernity, or that constituting period of the formation of national states since 1800 until our present. And as a part of that critical function of the historiographical discourse of modernity the importance that historiographers such as Hayden White (Metahistory: the historical Imagination in NineteenthCentury Europe 1973), added to many others such as Frank Ankersmit (The sublime historical experience 2010 [2007]), Francois Hartog (Evidence

\footnotetext{
1 "Antiquarians" busy in attracting the attention of the present towards "antiquities", "strangeness", the "exotic" "curious" things (KRIEGEL 1988, p. 221-264); (POMIAN 2003, p. 177-191). In this fondness for "ruins" of the past do not conceal, among other things, a certain melancholy (BREDEKAMP 1996).

${ }^{2}$ For a significant example related to the exercise of power, see MAZIN 2012.
} 
de I'histoire: ce que voient les historiens 2005) and Hans Ulrich Gumbrecht (Dimensionen und Grenzen der Begriffsgechichte 2006), just to mention some of them, ${ }^{3}$ are undoubtedly important. Not forgetting the early contributions of the beginning of the 1970's of Michel De Certeau (L'Ecriture de I'histoire 1975) and Michel Foucault (L'archéologie du savoir 1969) in an effort to reveal to us the hidden or unrecognized mechanics in the production of all discourse about the past.

Parting from the abovementioned it could be thought that history, as an academic discipline, is immersed in a period of revision and transformation of many of the categories of analysis, ways of narrating and periodizing, that have given sustenance and structured its discursive shapes built mainly since the $19^{\text {th }}$ Century. For many, it is true, this "revisionism" does not mean anything more than the destruction of history or the end of history as it has been known and practiced.

The previous statement has led us to think ${ }^{4}$ that probably, nowadays, the historiographical production could be divided into two big fields: between the producers of monographies, whose volumes tend to grow exponentially, ${ }^{5}$ and that other terrain that worries less with scarcity or abundance of information, and concentrates mainly in clarifying the way how historical events are produced or have been produced. It is in this second level where my reflections and comments would be situated, about how a history of modern historiography could be rewritten, a subject which has occupied my mind for several years. My intention is concentrated then, only in presenting the incipient sketch of a possible answer to the such said question, in which will come into play, fundamentally, the relationship between history, science, truth, and credibility.

\section{From Philosophy to the Sociology of Science}

As we well know, the justification of history as a science closely followed, during a long time, the step marked by the philosophy of science. It was necessary that during the second half of the $20^{\text {th }}$ Century, sociology displaced philosophy for history to be able to establish a fairer relation with science in view of its standing as a discipline. The sociology of knowledge developed towards the middle of the last century has allowed re-describing a notion of immutable truth, absolute, not relative, when showing how cultural factors are also determining in the acceptance of truths, be they of a natural or cultural order (SAHLINS 2011). On the other hand, we know that history still maintains an ambiguous relationship with the progress of the so called exact sciences, without noticing that modern experimental science was also bound to factors and procedures not necessarily aseptic. Such recognition would lead to the establishment of

\footnotetext{
${ }^{3}$ For example, at the dawn of the new century, a renowned medievalist historian, lets us see his preferences (RUIZ-DOMENEC 2000).

${ }^{4}$ In concordance with other approaches from other disciplines, such as the history of cinema or of art (QUINTANA 2011; DIDI-HUBERMAN 2008; BELTING 2010; DANTO 1999).

5 Which would make true the forecast of Jorge Luis Borges for the $21^{\text {st }}$ Century, where the great nightmare of the historian would lie in the increasing difficulty in writing due to excess of material and information (QUINTANA 2011, p. 188).
} 
another type of relationship between history and science until now characterized by a subordinate relationship of one towards the other, and in this way, open up to a new dialogue, more equitable and profitable between both.

To approach the subject, I remit myself to some works of the so called Edinburgh School, in particular to the contributions of one of its members, Steve Shapin (1994, p. 3-41), who intended to make a social history of the truth to show its relativity before academic philosophers who would sustain the contrary. The truth, in this case, would be conceived only as one of the selection mechanisms that a society, a group, an individual performs in order to be able to function in his everyday life. Although it is not the same thing to know something than to wield a "truth", what would be important here would be to be able to distinguish the mechanisms through which an ordinary knowledge constitutes itself in "the truth".

Within this context, for this trans-disciplinary collective, "the treatment of the truth as an accepted belief", would constitute itself in the heuristic methodological guiding principle. Beginning by the fact that the truth can be pronounced from different voices and tones, it would be a question of knowing, how does each of its participants consider something true or false? This starting point leads them to put in between brackets - in the manner of a hermeneutic resource - their notion of truth to be open to the possibility of understanding what others have as a certainty. At the end, what the issue would be about is: being able to understand how the cultural variation takes place in relation to truth (POOVEY 1998 SHAPIN; SCHAFFER 1985; SHAPIN 2000). In this sense,

its task is to be able to show that a socio-historical approximation to the truth, rigorous and valuable, is possible to understand the complexity of the production of all kinds of truths. Of course they do it as a discussion and facing those (philosophy, a type of history, etcetera) who adopt a normativistic and legalistic (aprioristic) approach, in the sense that it is still possible to establish the truth, once and for all, as if it were a timeless substance.

\section{Truth, Mass Media and History}

Precisely, in my approach to the problem posed I also resort to the work of a dear colleague and friend, Alfonso Mendiola, a specialist in the $16^{\text {th }}$ and $17^{\text {th }}$ Centuries. In his work Retórica, comunicación y realidad: la construcción retórica de las batallas en las crónicas de la conquista (2003), Mendiola has advanced some of the issues related to the problem about how to historize the truth in history. An approach, that to begin with, tries to see the way how to desubstantialize or pluralize the notion of truth.

One of the main aspects of his book is to know how, in scientific modernity, the topical (clichés) were formed, and how they displaced and, little by little, substituted the traditional forms imbricate in the Renaissance rhetoric art. The analysis suggests, roughly, that modern topical forked in two directions: on one side, there would be truths as a result of the explanation caused by laws (nomologic deductive model) and, on the other side, there would be truths, as a result of the comprehensive explanation of a polyvalent and contextualist 
nature. The first pole would belong to the science of nature and the second to the history understood as a science of culture. Seen in this way, scientific modernity would oscillate in two opposite directions: between the experimental scientific reason, on one hand, and the hermeneutic, weak or relative reason, on the other.

To satisfactorily clear this classical counter position, the following hypothesis would be postulated as the solution. In the production of truth or sense of reality, communication technologies count for more than subjective psychic structures. In this way, what would be called as "science" would be the progressive result of a technological change in the means of communication and not, as it used to be thought, as the result of a genial mind. Following this reasoning, it could be added that then, he who is able to understand the workings of the communication mass media would have better elements to understand the production of different versions of reality or of truth. ${ }^{6}$

If we consider this binomial (production of knowledge/evolution of mass media communication) it is possible to show that the dualist model absolute/ relative, explanatory/comprehensive, exact/hermeneutical, would correspond to the growing impact of the invention of printing in the calligraphic culture. One of the most original contributions of Mendiola's investigation, beginning with the analysis of the chronicles of the of the conquest, consists in showing the relation that exists between some of the principles that regulate modern scientific production and the installation of the culture of the written word as a 366 dominant form of communication in the establishing of the social agreements. In a later essay, Mendiola will go deeper into a fundamental distinction to understand such installation and its repercussions as the way of reaching a consensus about what is false and the truth: what exists between the oral and written forms of communication. While in the first case the production of what is real emerges from the distinction between speech (the sound) and the thing simultaneously with the moment in which it happens, the step of writing - as taking notes - to writing - as a form of communication, implied the possibility of separating the representation from the thing being referred to (LUHMANN 2002, p. 3-21; MENDIOLA 2002, p. 11-38). In that way, instead of writing disappearing to delve into reality, writings (thanks to their spreading through printing presses) turn into a condition of possibility and warranty of all truth and, at the same time, in the regulating instrument of the relation between what is real and what is unreal. The act of writing and its diffusion turned gradually into the referent of that referred to, indicating with it the possibility of distinguishing between what was written and the observed reality, natural or cultural (DE CERTEAU 1975). Under the mandate of observing with our own eyes, without intermediaries, scripture would function as the mirror in which reality is to be reflected. A mirror in constant perfectioning due to the mistakes glimpsed or to new findings. In that sense, especially since the $17^{\text {th }}$ Century, 
the culture of printed matter transformed itself in the referent of reality and possibility condition of all future truth.

A second aspect worth highlighting related to the transformation operated mainly in the $20^{\text {th }}$ Century, and that has been turning the classical forms of truth production into a problem, is the development and amplifying of distant communication through electronic means. Its impact can be observed in the review to which the notion of established truth has been submitted, established by the alliance between world and writing. ${ }^{7}$ The sociology of knowledge and analytical philosophy of language are also some expressions of the attempt to disobjectivate the notion of truth elaborated during the early modernity. These "sociologies" and "philosophies", critical no doubt, are unthinkable without the establishment of a new scenario in the forms and mass media communication. Starting from these considerations it can be explained that the $20^{\text {th }}$ Century has taken distance from a model of science made up during the expansion of the culture of the written, during the second half of the $18^{\text {th }}$ Century, without which the intellectual movement around the Encyclopedie and the Illustration is unexplainable. The "dare to think for yourself" of Kant is unthinkable without the explosion of the world of books among men and women of the second half of the $18^{\text {th }}$ Century and the will of taking distance from the so called "dark age", including the Renaissance imprint (KANT et al. 1980).

Also, since the works of Thomas Kuhn, although not only his, it can be observed how the history of science would come to occupy the space occupied before by the philosophy of science (BETANCOURT 2007). One of the implications of this displacement consisted in the recognition that the truth of the events observed does not depend exclusively of the exact description of them but, above all, by the way they are registered within a specific narrative. This statement implies the fact that the acceptance of the truth of truth is directly related to the same process in which it takes place. Hence it would follow: 1) that for the understanding of the history of truth, the formation and functioning of scientific communities should be observed, and 2) that the classical theoretical question about the scientific nature of the historical explanation, be transferred to that of research regarding the function of explanation in the narrative configuration of historical discourse.

When moving the location of truth of a merely individual production to a social or communitarian one, opens the question regarding the importance that the forms of communication have for that to happen or not to happen. This would imply assuming the theorem postulated by Luhmann that society is made up not by the sum of individual actions but by communications (LUHMANN 1996). From the previous, it would follow that truth is a relative good for the evolution of communication technologies (MENDIOLA 2002).

However, this postulate requires an ulterior precision related to the phenomena of communication and language in general. To this respect the distinction elaborated by Luhmann between language understood as a means

\footnotetext{
${ }_{7}$ No other is the context in which this "classical" book should be situated (LYOTARD 1990).
} 
and as a form of communication is fundamental. Language is analogous to other media where margins are unobservable, but that without them, it is not possible to define and envision the things and the objects. Thus, through the means of light, the objects are distinguished, or through the means of air the sounds are distinguished, or by means of the language forms (genres) of communication are distinguished. ${ }^{8}$ In these operations come into play, basically, the sense of hearing and that of vision in an unstable relationship, sometimes in a complimentarily relation, if not of open opposition. In the silent reading developed in western countries will tend to give priority to vision (external and interior) in detriment of hearing. This contradistinction between the ear and the eye will be important, for example, when discussing about if Herodotus was more reliable, as a historian, than Thucydides. Later, with the growing colonization that took place by writing, at the expense of circulating information, from ear to ear (turned into rumor, suspicious and dangerous) will arise within the interior of the system or form of writing "literary" genres, in which the increasing differentiation between the fiction tale and the veridical tale or historical tale will be included (COSTA LIMA 1988). In this sense it can be sustained that the language is not a form but a means of communication, through which societies acquire and create specific forms (LUHMANN 1996, p. 130-139; MENDIOLA 2003, p. 79-82).

In this way, we reach the nodal point of our argumentation. According to the theory of the Luhmannian society there would be no communication while the contact between an alter and an ego does not take place, between a transmitter 368 and a receiver. ${ }^{9}$ But at the same time, it is assumed that communication is one of the most improbable facts in which human beings find themselves immersed. However, - and that would be the central paradox on which the argumentation articulates or hinges - only from this improbability is that social systems emerge and develop, or the ways how humans are programmed to turn improbability into probability. In that sense it would be a productive paradox (LUHMANN 1996, p. 238-240).

If there is no society without communication, then around a probable history of historiography the central question would consist in knowing how out of the improbable identifications and recognitions are produced, between speakers and listeners, between writers and readers. The answer to the enigma would be in that parting from the initial communication deficit, societies and thought communities generate supplementary mechanisms to enable the triumph of yeses over the noes between the listeners. In relation to our research the question would be the following: what kind of mechanisms had to be generated to reinforce the acceptance and development of a type of historical and scientific communication? In this point is where there is a fundamental coincidence between Luhmannian sociology and historical sociology, represented by Steven Shapin.

One example of this is provided to us by Mendiola, starting from his study about the production and circulation of the chronicles of the conquest in the $17^{\text {th }}$

\footnotetext{
${ }^{8}$ For example for the literary field G. GENETTE et al. 1986.

${ }^{9}$ For example it should be explained how a statesman in some place manages to obtain $100 \%$ of the yeses in a referendum; a $100 \%$ that would imply full communicative contact between the politician and the "people".
} 
Century (MENDIOLA 2003). There, it can be seen how, in a society governed by a secondary oral culture - where the oral forms of communication coexist with the calligraphic written forms - the classical rhetoric manuals were adapted to reinforce and ensure the communicative interchanges established predominantly on the edge of orality. In this way, the resource of art of the old rhetoric allowed to give a certain temporary depth to social relationships branded by presentism and ensure new communicative links. But above all, rhetoric fulfilled the role of strengthening the possibility of obtaining the acceptance or recognition between an alter and an ego during this period. Besides, the use of rhetoric - supported on the incipient development of printing - coincided with the first outbreaks of the "methodical" revolt against the same rhetoric. It was a moment when the mandate of observation of nature with our own eyes, as a reaction to the growing multiplication and circulation of printed books, began imposing itself. Thus, the coming up problem, which belongs to the structuring of the scientific field, is related to the type of mechanisms that an increasingly literate society had to develop to solve the problem of distant communication implied in the growing production of printed matter. What kind of mechanisms were implanted in the substitution process of rhetoric to ensure the acceptance of non-allegoric empirical enunciates? The answer could be found in the emergence and development of the "symbolically generalized media", central notion in Luhmann's theory of society, to which I shall refer in the next section.

Beginning with the abovementioned factors it could be affirmed that modern science emerged simultaneously thanks to and against rhetoric; in other words, science was possible, in the measure rhetoric declined and lost credibility due, largely, to the increasing automatization of writing with respect to the spoken word. In this sense, it is not surprising - as studies of cultural history allow us to see, about that subject and period - that the scientific and literary societies that proliferated from the $17^{\text {th }}$ Century, retrospectively anticipate the formation of a modern public opinion (GOUBERT; ROCHE 1991, p. 219-254). Within this framework, the issue is about the type of resources that had to be developed in order to reinforce and convince the public through forms of communication mediated by the temporal spatial distance and the interposition of printed matter.

A possible answer can be unfolded into five aspects: 1) a supplementary measure to cover the own deficit of all communication, would have to do, as settled by Steven Shapin, with the development of a new type of "civility" or forms of politeness; 2) a new type of grammatical syntax is developed, a recursive writing, open to novelty; 3 ) a new sense of temporality appears, that widens the horizon of expectations (the future) in relation to the constrictions of the present; 4) A new sense of objectivity built from the distinction between representation and reality arises and, 5) there would be a displacement of rhetoric by experimental science that implied the construction of another type of social memory or ways of remembering.

Perhaps this fifth aspect is the most relevant due to its implications regarding the revision we are making in relation to the notion of truth in history, since it means an opening towards the understanding of historiography as a 
type of cultural memory (BIZIERE; VAYSSIERE 1995, p. 232; DOSSE 2000, p. 169-193). Mendiola reminds us that rhetoric was, above all, "a memorizing technique". In an oral society, of "few books" and incipient or very localized libraries, based on the art of rhetoric a type of spatial and interior memory was developed. The place of the memory is internal and it is reached through the imagination to evoke what is already known as worthy of being remembered. ${ }^{10}$ In return, under the scientific regime, the library is the objectivating place of memory; it is exterior to who remembers or learns something new. The accumulated knowledge and everyone's sight is confronted with the field work, with the travels and observations on the terrain, a fashion which will tend to acquire great relevance from the $18^{\text {th }}$ Century on. The laboratory turns into the last link that puts at stake the bookish reality and the empirical one that confront the natural languages with the specialized ones. If in the rhetorical society the memory makes use of the authorities or of the sages or classicists to recreate knowledge and tame fate, the question is to see how scientific modernity in its rebellion against this knowledge production scheme (through external and internal images) generated its own authorities to reinforce and extend its domains (MENDIOLA 2003, p. 160-197).

\section{Truth, history and credibility}

We have inherited a notion of truth that aspires to establish a full or approximate correspondence between representation and that which is being

370 represented, writing and the world. However, leaving behind its "naïveté", this notion has run into the impossibility of fixing or finding the exact and final word to designate things, in the measure that the form "truth" is relative to the environment used for its observation and enunciation. From there derives, in part, the need of disposing of a concept of truth that is historical, a concept of truth that is contingent, which is not the same thing as relative or subjective truth. It also requires undoing a concept of subjectivity adjusted to the model of science implied in the distinction subject/object, and in a theory of the international action centered in the conscience of isolate individuals. ${ }^{11}$

The reprogramming of the notion of truth from this perspective does not imply falling into the abyss of relativism and arbitrariness, as some would like to lead us to think, because the concept is not derived from the mind of an individual but from society. Truth, in that sense, is not the exclusive patrimony of isolated individuals nor is it the result of the statistical sum of all the individuals, but rather the result of the evolution of forms of communication throughout history. In such a way that each one of these "forms" would correspond with a type of production of truth, as follows: 1) allegorical that takes the form of the metaphor or game of similes; 2) empirical or positive that takes the form of descriptions-explanations; and 3) cybernetic that takes the form of virtual image. These three classes would correspond with the formation of three

${ }^{10}$ A good example of the development and functioning of this type of memory can be seen in SPENCE 2002. ${ }^{11}$ Such is Habermas' task when trying to trace "the prehistory of modern positivism" (HABERMAS 1968, p. 9). 
types of memories without which there is no possibility of communication: 1 ) introspective corporal memory, 2) memory centered on the subject and 3) virtual decentralized memory. To indicate that the classes of truth are not relative to the action of the individual but to the forms of communication in which the action is inscribed, supposes the emergence of three classes of subjectivity relative to three classes of communication: 1) oral, 2) written, and 3) telematic. In each one of them subgenres are presented at the same time or forms of coexistence and hybridization that fulfill the specific functions in each one of the forms of communication. At the same time, each one of the forms generates forms of differentiated temporality and socialization, familiar; educational, legal, and political forms.

The key to this sociological taxonomy would lie in the distinction between language as a means of communication and language as a form of communication. The language, as it has been said, is a means and is only structurable from its forms that refer to the objects indicated. In this scheme one of the main challenges for the historical and sociological research would consist in being able to identify and maneuver, with possible overlaps or sub-configurations, which could occur in the transition from one form of communication to others, both in relation to the transformation of the form as in the coexistence with other forms. In this sense, one of the findings of Mendiola's research has to do with the use he makes of the notion of "secondary orality" to explain the coexistence of orality (as dominant means of socialization in the pre-modern era) and the writing which led to the use of rhetoric to reinforce the agreements among those present; in other words, to give way from communicative improbability to a probability among others. It is true that the development of rhetoric was presented also as a means to produce and preserve the necessary knowledge for the functioning of a society ruled by the interactions among presents, and that would give way, as said before, to the constitution of other forms of production and conservation of the knowledges, of our own scientific modernity.

Within this framework, a provisional periodization could be drawn with the following results. We would have that during the emergence of scientific thought between 1550 and 1650, approximately, the first great debate about the method to control and manage the knowledge that is produced, not any more by means of rhetoric (that requires of a certain number of authors and scholars), but by means of the observation of nature which has been sedimenting in the books. The operation is not any more that of an individual that knows because he remembers, but that of an observer who verifies if what is known is true or false when confronting what is known with the new information offered by the environment. In this way, writing (and not introspective memory), gradually has become the benchmark of reality and referred truth.

To follow, a second period could be outlined that goes from the end of the $17^{\text {th }}$ Century until the $19^{\text {th }}$, where the development and codification of a second way of observing and producing knowledge took place. During this span, next to natural science, a knowledge about humanity and society developed, an ethnographic, anthropological and sociological knowledge, in conflict with the versions taken 
from secondary orality or rhetoric; that is to say, a scientific writing that proceed not in accordance to the orality code but of writing (DUCHET 1995). Rhetoric, which served as support to oral memory, was insufficient when the sense of sight became more important than hearing, and it accounted for a major complexity and extension of the world, where the individual was only one more component among others. Thus, writing emerged as the support of scientific thought.

Retaking the idea of communication as probability of the improbable which certainly moves away from the thesis of consensus and comprehension of the traditional hermeneutics, in the Haberman's style or in some aspects from that of Gadamer - the key question to recognise the evolution of truth in history would consist in knowing what type of resources that type of communication developed based on writing to reinforce, to make probable the improbable of "scientific communication"? If rhetoric fulfilled the function of making possible the impossibility of communication, face to face, what type of "rhetoric" did modernity have to develop to make possible the impossible in the relations of long distance communication imposed by the logic of the written and printed matter? What type of writing did it have to develop to obtain the endorsement of the reading public situated on the opposite side of the empirical observer, about situations of which it was not an eyewitness or co-participant of the memory represented in the writing? In what way was the necessary trust generated to make the telling of facts, of findings and experimenting credible, credit worthy and not the product of a hoax?

372 In relation to the issue about how the "non-rhetoric scientific modernity" managed to solve the problems of improbability/probability of all communication within the more complex margins belonging to writing, Luhmann in his sociological theory stated - in discussing with Parsons - that the place of rhetoric was taken up and occupied by symbolic generalized media. This type of means are money (for economy), the law (for politics), the truth (for science), and love (for intimacy) (LUHMANN 1998, p. 9-73).

In fact, I believe that the boundaries of these issues and of this approach inscribe the contributions of some sociologists and historians of science who show that the generation of new knowledges, unsubstantiated in the introspective memory, required the development of a new virtuosity or "civility" in order to generate the necessary trust for their acceptance. Among these are, besides Kuhn and Steven Shapin, others such as Alexander Koyré or Bruno Latour, Lorraine Daston.

When considering Shapin's essay "La gran civilidad: la confianza, la verdad y el orden moral" it can be thought in the community of historians and the process that led to the institutionalization of historiography, understood as "scientific"; in other words, as a space equipped with technical, epistemological instruments and bodies of diffusion (periodical publications and books). Spaces from where a type of statements will be pronounced about the past facing a society ready to accept them as true. Factual statements corresponding to the state of real things, similar to the statements that began being generated in Europe in the $17^{\text {th }}$ Century of the type: "Olive oil freezes in a Russian winter". 
If it is sustained that historical truth does not change, it should also be supposed that there is no space for sociology and history. It will also continue to be supposed that truths are universal insofar as they do not depend neither of space nor time of observation. But if the opposite is assumed, then the posture should be maintained that there is no production of truth independent of the society in which it is produced. In this case truth looses its character of immutable substance and it becomes a good that evolves within the framework of collectivities. Therefore, its evolution can not be attributed to an individual who defines the pertinence of the selection of his research but to the functioning of a collectivity that establishes its selections and stabilizes them. In this measure the study of history is a cause for sociology.

Within this perspective, configured since half a century ago in the works of history and sociology of science, a social history of the historical truth would annul the dominant romantic and heroic visions where historians usually appear as privileged beings that carry and make the truth in history. In light of this postulate it should be observed how historical knowledge has been the result of evaluations and actions of a particular community, delimited by the incorporation of the demands of knowledge and of the institutionalized behavior of the community. In that sense, the communities of historians should describe themselves from their "economies of truth" (SHAPIN 1994, p. 5). These "forms" can be observed through their sociological, philosophical, and historiographical phrases.

The development of linguistic pragmatism has allowed illuminating a second aspect related to the constitution of the truth in the bosom of a community. $A$ pragmatic analysis of the expressions would allow seeing, for example, how the judgments of truth culminate not purely in a vision of the world but in a collective way of acting. To this respect, the truth would consist of, not merely in the formulation of an aseptic idea but, in the capacity of generating actions that turn true that idea. This step - that coincides with the problem of making possible the impossible in communication - is proposed in moral terms in Shapin's research for the conformation of scientific communities during the $17^{\text {th }}$ and $18^{\text {th }}$ centuries.

Given the collective nature of making or producing truth in history, the individuals who participate in this "game" need one another to cover their material requirements, confirm the states of the questions, produce new knowledges and, even to be skeptical about what is known. Therefore, for knowledge to be effectively accessible to an individual, there must also be a moral bond between the individual and other members of the community. If this bond fails, the information that circulates can most probably not culminate in communication and, thus, there may be no "truth". The word that designates that "moral bond" is trust that surely can be translated as "credibility" (Shapin). The problem of truth would consist then, in knowing how an alter makes it credible for an ego, that what it is stating is true and not a mere opinion.

How do we obtain the other's "trust"? Only by fulfilling the expectations of previously contracted agreements. Yet, if the historical truth looses its immutable character then we must ask ourselves how does this type of memory function 
that makes us see the facts of the past as they were, when they could have been different? When we deactivate an epistemological history of "naturalist" cut, the discipline of history opens to think itself as part of a larger phenomenon: culture and its relation with the way how societies remember of forget. ${ }^{12}$ For the time being that seems to be the most plausible way to overcome the apparent relativism and bewilderment among those who believe in the end of history when the classical epistemology of the first modernity collapsed, due to the incorporation and social dissemination of the new electronic communication media of the $20^{\text {th }}$ Century. From "that place" it has been considered the possibility of rewriting the history of the discipline of history, or the re-description of the evolution of "truth economics" of the community of historians inscribed in time, wherein come into play principally four words: history, science, truth and credibility. ${ }^{13}$

\section{Bibliographic References}

BREDEKAMP, Horst. La nostalgie de I'antique: statues, machines et cabinets de curiosités. París: Diderot Editeur, 1996.

BELTING, Hans. La historia del arte después de la modernidad. Traducido por Issa Maria Benítez Dueñas. México: Universidad Iberoamericana, 2010 [2003].

BETANCOURT, Fernando. El retorno de la metáfora en la ciencia histórica contemporánea: interacción, discurso historiográfico y matriz disciplinaria. México: Universidad Nacional Autónoma de México, 2007.

BIZIERE, Jean Maurice; VAYSSIERE, Pierre. Histoire et historiens: Antiquité, Moyen Age, France moderne et contemporaine. Paris: Hachette, 1995.

CASACUBERTA, David; ESTANY, Anna. ¿Eureka? El trasfondo de un descubrimiento sobre el cáncer y la genética molecular. Barcelona: Tusquets, 2003.

COSTA LIMA, Luiz. Control of the Imaginary: reason and imagination in Modern Times. Translated by Ronald W. Sousa. Minneapolis: University of Minnesota, 1988.

DANTO, Arthur C. Después del fin del arte: el arte contemporâneo y el linde de la historia. Barcelona: Paidós, 1999.

DE CERTEAU, Michel. L'écriture de I’histoire. París: Gallimard, 1975.

DIDI-HUBERMAN, Georges. Ante el tiempo: historia del arte y anacronismo de las imágenes. Buenos Aires: Adriana Hidalgo editora, 2008.

DOSSE, François. L'Histoire. Paris: Armand Colin, 2000.

DUCHET, Marcel. Anthropologie et histoire au siecle dês Lumieres. Postfacio de Claude Blanckaert. Paris: Albin Michel, 1995.

\footnotetext{
12 To this respect we are conscious it is a polemic ambit which demands more clarification: not all historians and philosophers of science would share this enunciate (CASACUBERTA; ESTANY 2003; ESTANY unedited).

13 Precisely, about this kind of problems Francois HARTOG 2013 has published one of his last books.
} 
ESTANY, Anna. Cognitive approach on the relations science-technology. Manuscrito inédito (fotocopia).

FORASTIERI DA SILVA, Rogério. História da Historiografia: capítulos para uma história das histórias da historiografia. Sao Paulo: EDUSC, 2001.

GENETTE, G. et al. Théorie des genres. Paris: Du Seuil, 1986.

GOUBERT, Pierre; ROCHE, Daniel. Le français et l'ancien régime. 2: culture et societé. Paris: Armand Colin, 1991

HABERMAS, Jurgen. Conocimiento e interés. Traducido por Manuel Jiménez Redondo Madrid: Taurus, 1982 [1968].

- El discurso filosófico de la modernidad (Doce lecciones). Traducido por Manuel Jiménez Redondo. Madrid: Taurus, 1989.

HARTOG, François. Croire en I'histoire. Paris: Flammarion, 2013.

KANT et al. Was ist Aufklarung? Thesen und Definitionen (Erhard Bahr Ed.). Stuttgart: Reclam, 1980 [1783-1784].

KRIEGEL, Nadine. L'histoire a I'Age classique 3/ Les Académies de

I'histoire. Paris: Quadrige/Presses Universitaires de France, 1988.

LUHMANN, Niklas. La ciencia de la sociedad. Traducido por D. Pappe, B. Erker y L.F. Segura. México: UIA/Anthropos/Iteso, 1996

Los medios generalizados y el problema de la contingencia. In: Teoría de los sistemas sociales (artículos). México: UIA/ ITESO, 1998, p. 9-73.

. La forma escritura. Estudios Sociológicos, v. XX, n. 58, p. 3-21, 2002.

LYOTARD, Jean-François. La condición postmoderna. México: REI, 1990.

MAZIN, Oscar (ed.). Las representaciones del poder en las sociedades hispánicas. México: El Colegio de México, 2012.

MENDIOLA, Alfonso. Las tecnologías de la comunicación: de la racionalidad oral a la racionalidad impresa. Historia y Grafía n. 18, p. 11-38, 2002.

- Retórica, comunicación y realidad: la construcción retórica de las batallas en las crónicas de la conquista. México: UIA, 2003.

POMIAN, Krzysztof. Des saints reliques a l'art moderne: Venise-Chicago XIIIe-XXe siècle. Paris: Gallimard, 2003.

POOVEY, Mary. A history of the modern fact: problems in the sciences of wealth and society. Chicago: Chicago University Press, 1998.

QUINTANA, Angel. Después del cine: imagen y realidad en la era digital. Barcelona: Acantilado, 2011.

RUIZ-DOMENEC, José Enrique. Rostros de la historia: veintiún historiadores para el siglo XXI. Barcelona: Península, 2000. 
SAHLINS, Marschall. La ilusión occidental de la naturaleza humana. Traducido por Liliana Andrade Llanas y Victoria Schussheim. México: Fondo de Cultura Econômica, 2011.

SHAPIN, Steven; SCHAFFER. Leviatán and the air-pump: Hobbes, Boyle, and the experimental life. Princeton: Princeton University Press, 1985.

A social history of truth: civility and science in seventeenth-century England. Chicago: Chicago University Press, 1994

- La revolución científica: una interpretación alternativa. Barcelona: Paidós, 2000.

SPENCE, Jonathan D. El palacio de la memoria de Matteo Ricci: un jesuita en la China del siglo XVI. Traducido por Mabel Lus González. Barcelona: Tusquets, 2002.

ZERMEÑO PADILLA, Guillermo. La historia común es bastante compleja. Historia y Grafía, n. 36, p. 75-104, 2011.

. De viaje tras el encuentro entre archivo e historiografía. Historia y Grafía, n. 38, p. 13-57, 2012. 